\title{
Riikka Pöyhönen
}

\section{Teksti- ja kontekstilähtöisyydestä akselimalliin. Lukion kirjallisuudenopetuksen kehittämissuuntia}

Äidinkielen ja kirjallisuuden ammattilaiset ovat viime aikoina keskustelleet paljon kirjallisuuden opettamisesta kouluissa, pääasiassa kahdelta kannalta. Toisaalta on haluttu kehittää äidinkielen ja kirjallisuuden ylioppilaskoetta ja siihen tähtäävää opetusta. Tämä aihe on saanut valtamediassakin julkisuutta Helsingin Sanomissa ja Aamulehdessä, ja siihen ovat osallistuneet muun muassa Elina Kouki ja Pirjo Sinko sekä useat ylioppilastutkintolautakunnan jäsenet, esimerkiksi Ylioppilastekstejä-julkaisusarjan kautta. Toisaalta on pohdittu myös ylipäätään kirjallisuudenopetuksen sisältöä, ja erityisesti keskustelua on herättänyt kirjallisuudentutkimuksen iänikuinen tekstin ja kontekstin suhde. Tähän vastakkainasetteluun on edellä mainittujen lisäksi osallistunut useita kirjoittajia. ${ }^{1}$ Olen vasta viittä vaille valmis opettaja, mutta kiinnostunut osallistumaan keskusteluun ja tuomaan mukaan aloittelijan näkökulman. Olen kirjoittanut aiheesta pro gradu -tutkielman Tampereen yliopistossa keväällä 2011 otsikolla "Kertojan käsitteen hallinta esimerkkinä abiturienttien tekstitaidoista ja opetuksellisista haasteista".

\section{Kehittämisen monta tapaa}

Koskaan tilanne opetuksessa ei ole niin hyvä, ettei kehitystyötä tarvittaisi. Se vaikuttaa olevan useiden keskustelijoiden yhteinen mielipide. Enemmän eri mieltä ollaankin kehityskohteista ja -menetelmistä. Voi olla, että tämänhetkinen vahvasti tekstianalyysiin pohjautuva opetus ei palvele nuoria, joiden tulisi oppia nauttimaan kirjallisuudesta oman elämänsä ja ympäristönsä käsittelyn välineenä. Opetuksen keskittymispisteen tulisi siis siirtyä tekstilähtöisyydestä kontekstilähtöisyyteen. Toisaalta voi olla, että tekstianalyysi on juuri se, mitä kirjallisuudenopetuksen kuuluu olla, mutta yhteiset pelisäännöt puuttuvat. Joka tapauksessa tekstilähtöinen tapa ei tällaisenaan ole luonut opetukselle yhdenmukaista ja selkeää kirjallisuuden opetussuunnitelman pohjaa. Tämä on havaittavissa keskustelussa lehtien palstoilla, mutta myös Elina Koukin väitöskirjan (2009) tuloksena ja hänen luentojensa saavuttamassa suosiossa äidinkielen ja kirjallisuuden opettajien keskuudessa.

Saman perusongelman voi havaita tutkielma-aineistostani. ${ }^{2}$ Aineisto koostuu 84 abiturientilla toteutetun kyselyn vastauksista. Kyselylomake on tyrkyttänyt erilaisia kertojaan liittyviä alakäsitteitä ja moni on aluksi määritellyt ne onnistuneesti. Silti analyysitehtävässä vain 31 abiturienttia 84:stä on osoittanut pystyvänsä tekemään 
teksti- tai kerrontateknisiä havaintoja. Toki abiturientit olivat kyselyvaiheessa vasta kertauskurssilla ja heillä oli vielä noin puoli vuotta aikaa valmistautua kevään kirjoituksiin, mutta osaamisen taso oli siitä huolimatta hälyttävän alhainen. Mielenkiintoista on, että kun analysointitehtävässä mainitsemani 31 vastaajaa oli havainnut tekstistä kerrontateknisiä seikkoja, vastaava lukema sisällöllisten ja kontekstuaalisten havaintojen puolella oli 57 vastaajaa: Pyydettäessä analysoimaan novellin kertojaa $99 \%$ vastaajista on käyttänyt minä- tai ensimmäisen persoonan kertojan käsitettä. Sisällöllisiä ja kontekstuaalisia havaintoja esimerkiksi kertojan luonteesta, sukupuolesta, iästä tai novellin juonikuvioista on osannut esitellä 57 vastaajaa. Kerrontateknisiä havaintoja esimerkiksi kertojan sanavalinnoista tai käytetystä aikamuodosta, tiedon määrästä, luotettavuudesta ja niin edelleen esittää vain 31 vastaajaa. Kysely on toteutettu syksyllä 2010 eli kolme ja puoli vuotta ylioppilaskokeen edellisen kertojakysymyksen ja vajaa vuosi Koukin väitöskirjan julkaisun jälkeen. Teksti- ja kerrontateknisiin seikkoihin keskittyvää ylioppilaskoetta ja sitä kautta lukio-opetusta on syytetty toimimattomuudesta jo jonkin aikaa. ${ }^{3}$ Olin olettanut, että kun yo-lautakunta edelleen ainakin toistaiseksi vaatii tekstilähtöisyyttä, opiskelijat olisivat osanneet analysoida tekstin kerronnallisia keinoja monipuolisemmin. Siitä huolimatta suurin osa tehdyistä havainnoista koski kertojan sukupuolta tai novellin juonta, tai vastaaja oli kehittänyt tarinoita kertojan lapsuuden traumoista.

Pohdittuani tutkielmassani molempia näkökulmia saavutin yhden merkittävimmistä tutkimustuloksistani: Teksti- tai kontekstilähtöisyys ei kumpikaan voi itsessään ratkaista kirjallisuudenopetuksen suurta solmukohtaa. Ongelmat ovat nyt syvemmällä. Kuka oikeastaan tällä hetkellä tietää, mitä äidinkielen ja kirjallisuuden oppimäärän lukiossa opiskelleen nuoren pitää Suomessa hallita? Oppilaalla, opettajalla, oppikirjojen tekijöillä, opetushallituksella, ylioppilastutkintolautakunnalla ja jatko-opiskelupaikoilla on kaikilla oma käsityksensä, mutta käsitykset voivat erota ja tuntuvatkin eroavan toisistaan suuresti. Tekstilähtöisellä opetustavalla on puolustajansa ja vastustajansa, samoin kuin vaikuttaa olevan esimerkiksi Juha Rikaman (mm. 2011) ehdottamalla kontekstilähtöisellä opetustavalla. Opetusta ja oppimäärän loppukuulustelua mullistettiin juuri äsken vuonna 2007. Miksi vastaavankokoinen muutos hyppäämällä toiselle ärilaidalle tekstistä kontekstiin auttaisi asian nykytilannetta yhtään enempää?

Nähdäkseni tekstiteknisten taitojen hallinta (esimerkiksi kerrontatekninen havainnointikyky) on hyvä kirjallisuudenoppimisen mittari, sillä monipuolisten tekstien analysoimista voi hyödyntää työ- ja arkielämässä vastaan tulevien tekstien lukemisessa ja oikein ymmärtämisessä. Myös puhdas kirjallisuudesta nauttiminen on mielestäni opettamisen arvoista. Myöskään keinoja oman elämän ja ympäröivän maailman käsittelemiseen ja työstämiseen ei voi nykypäivän ääritekojen maailmassa tarjota nuorelle liikaa. Nykyisen opetussuunnitelman (LOPS 2003, 32) mukaan yksi opetuksen tavoit- 
teista on opettaa opiskelija nauttimaan kulttuurista. Mielestäni kaikkia ei voi pakottaa nauttimaan kirjallisuudesta, ja miksi edes pitäisi? Toiset pitävät liikunnasta, toiset matemaattisesta ongelmanratkaisusta, toiset kirjallisuudesta. Lukio-opetuksen tavoitteena tulisikin pitää mieluummin sitä, että opiskelija löytäisi oman kirjallisuussuhteensa. On yksilökohtaista, mitä kirjallisuus kullekin antaa: elämyksiä, tukea, pohdittavaa, ratkaistavaa ja niin edelleen. Seuraavaksi voidaan kysyä, miten opiskelijan kirjallisuussuhdetta voidaan kuulustella ylioppilaskokeessa. Siihen on yksinkertainen ratkaisu: tarjoamalla useita vaihtoehtoisia kysymystyyppejä. Tekstitekninen taito on vain yksi kirjallisuuden osa-alue. Myös kontekstisidonnaisia pohtivia tehtäviä tarvitaan. Käytännössä siirtyminen monipuoliseen kysymistapaan vaatisi opetussuunnitelman ja oppikirjojen päivittämistä. Totta kai opiskelijoille täytyy opettaa sekä tekstitaitoja että kontekstipohdintaa ennen uudenmallisia ylioppilaskoekysymyksiä. Nyt elämme sikäli onnekasta aikaa, että kuin tilauksesta opetussuunnitelman uudistaminen on tällä hetkellä ajankohtaista. Lehtien palstoilla väittelystä olisi nyt mahdollista siirtyä käytännön muutoksiin helposti.

\section{Käsitteiden opettamiselle voidaan sopia yhteiset pelisäännöt}

Koska olen itse kiinnostunut tekstilähtöisestä kirjallisuudentutkimuksesta, käsittelin pro gradu -tutkielmassani yhtä mahdollista opetustapaa, jonka kehittämisen koen tärkeäksi. Tällä hetkellä tekstitaitojen opetus ja kuulusteleminen ontuvat siksi, että työskentelyvälineinä on liian tiukkarajaisia käsitteitä, joiden määrittelystä edes opettajakunnalla ja ylioppilastutkintolautakunnalla ei ole yhtenevää kantaa. Esimerkkinä voidaan pitää kertojan käsitettä. Elina Kouki (2009, 147-148; 166) moittii väitöskirjassaan ylioppilaskokeen sensoreiden tehneen toisistaan poikkeavia ja jopa virheellisiä arvosteluja kokelaiden käsitteidenkäytöstä. Lars Sundin romaanin tekstipalassa on lautakunnan arviointiohjeiden mukaan minäkertoja, jolla on kaikkitietävän kertojan ominaisuuksia. Koukin mukaan tällainen kertoja ei edes ole mahdollinen, ja kun kokelaat ovat kekseliäästi luoneet kaikkitietävän minäkertojan käsitteen, Kouki pitää sitä vääränä käsitteenkäyttönä. Mitä sinä tekisit, jos olisit (tai olet) opettaja? Olisitko antanut kaikkitietävän minäkertojan käsitteen käytöstä kunniapisteet luovasta ja aidosti tekstilähtöisestä analysointi- ja erittelytaidosta kuten Leena Kirstinä (2011, 52) tai Samuli Hägg $(2011,39)$, vai vetänyt punakynää alle kaikkitietävän kertojan kertojatyypin sekoittamisesta minäkertojan kertojatyyppiin kuten Elina Kouki (2009, 168)? Kuinka kollegasi samassa koulussa olisi toiminut? Miten porilaisen ja imatralaisen tai 25- ja 55-vuotiaiden opettajien arviot olisivat eronneet toisistaan?

Kirjallisuudentutkijat voisivat helposti kiistellä aiheesta tämän lehden sivuilla monen numeron ajan. Esimerkiksi Jan Alberin mukaan kaikkitietävä minäkertoja on käyttökelpoinen käsite, sillä hän käyttää sitä itse. Hänen mukaansa Rick Moodyn 
novellissa "The Grid" (1995) on "kaikkitietävä ensimmäisen persoonan kertoja, eli henkilökertoja, joka tietää huomattavasti enemmän kuin kukaan 'tavallinen' ihminen voisi tietää" (Alber 2010, 57). Toisaalta esimerkiksi Jonathan Culler kirjoittaa kaikkitietävyyden perusartikkeliksi muodostuneessa kirjoituksessaan "Omniscience" (2004), että lukijalla on vain fantasia kaikkitietävästä kertojasta, ja itse kaikkitietävyys on täysin ongelmallinen käsite kirjallisuuden analysoinnissa. Seymour Chatman taas on kirjoittanut jo vuonna 1998 Encyclopedia of the Novel-sanakirjassa, että kertojia ei kannata analysoida yrittämällä tunkea ne johonkin kategoriaan. Hänen mukaansa kertojan analyysin pitää olla paremminkin kuvailua kertojaan liittyvien käsitteiden avulla. (Chatman 1998, 908.)

Miksi jotkut haluavat pyrkiä siihen, että kirjallisuudenopetus kouluissa tähtäisi juuri lokerointilähtöiseen analysointitapaan? Juha Rikaman (2011) esittelemä keskusteluun muodostunut kolmikantasysteemi pitää yhtenä näkökulmana sisällään juuri tällaisen ahdaskatseisen yritelmän. Rikama on nimennyt käsityksen Leena Kirstinän ja Elina Koukin kannaksi (ks. Kouki 2011). Tätä käsitystä puolustavien mukaan kirjallisuudentutkimuksessa on olemassa tärkeä "ydinkäsitteistö, joka soveltuu tarpeeksi yleispätevästi erilaisten kaunokirjallisten tekstien analyysiin”. (Rikama 2011, 44.) Ainakin Kouki tuntuu ajavan perinteisten, klassisesta narratologiasta perittyjen yleiskattavien lokerokäsitteiden asiaa, mikä on mielestäni mahdoton taktiikka. Kirjallisuus ei yksinkertaisesti ole tieteenala, jossa käsitteet olisivat yksiselitteisiä. Emme tutki solubiologiaa vaan luovaa, muuttuvaa sanallista leikkiä. Täten olen samaa mieltä Samuli Häggin (2011) kanssa siitä, että ei ole olemassa sellaisia kirjallisuustieteellisiä peruskäsitteitä, jotka suoraan sopisivat kaikkien tekstien analysoimiseen. Toki olisi helppoa, jos voisimme valita tietyt käsitteet ja opettaa ne mielivaltaisesti sopimuksemme mukaan, mutta sitten joutuisimme sensuroimaan tiukalla kädellä lukiolaisille sallittua kirjallisuutta. Valitsemamme käsitteet eivät nimittäin - vaikka kuka olisi valitsemassa - sopisi kaikkien kirjaston hyllystä löytyvien teosten tulkintaan. Emme siis voi valita kirjallisuustieteellisistä käsitteistä kolmea tärkeintä ja keskittyä niihin. Toisaalta mielestäni on myös mahdotonta olettaa, että nykyresursseilla tai muutenkaan lukion oppimäärän voitaisiin sisällyttää kaikki kirjallisuustieteessä käytetyt käsitteet ja niiden käyttö eri tilanteissa.

Kuten jo aiemmin kirjoitin, Juha Rikaman näille kahdelle kannalle verrokiksi esittelemä "Juha Rikaman kanta" (2011) ei kyllä toimi sekään. Rikaman mukaan ihmiset lukevat ja ymmärtävät kirjallisuutta ja pystyvät käymään lukemastaan merkittävää keskustelua tuntematta yleensä lainkaan kirjallisuustieteellisiä käsitteitä (mt.). Kuitenkin, jos lukijalla ei vaikkapa ole mitään käsitystä ja harjaannusta niistä kerronnallisista keinoista, jotka mahdollistuvat proosassa, on hankala tulkita esimerkiksi Riikka Pulkkisen Totta -romaanin mystistä nimenvaihdosta. ${ }^{4}$ Miksi riidellä kirjallisuudenopetuksessa siitä, onko teksti- vai kontekstilähtöinen lähestymistapa parempi, kun tämä 
kiistely on - onneksi - jo laimentunut tieteellisen tutkimuksenkin puolella? Mikään ei viittaa siihen, että kontekstilähtöisen kirjallisuudentutkimuksen kannattajat osaisivat tehdä sen parempia oppikirjoja tai ylioppilaskoekysymyksiä kuin tekstianalyytikotkaan. Kumpikaan ei pärjää yksin.

Loppujen lopuksi kirjallisuuden parissa työskentelemisessä ei edes voida erottaa täysin toisistaan tekstiin ja kontekstiin keskittyviä lähestymistapoja, sillä ne toimivat aina jollakin tasolla limittäin. Jos emme lainkaan kiinnitä huomiota siihen, voimmeko luottaa tarinan kertojaan, tekstin tulkinta voi jäädä hyvinkin vaillinaiseksi tai jopa virheelliseksi. Toisaalta ilman tekstin kunnollista tulkintaa on vaikea esittää näkemyksiä tarinan henkilöistä tai kertojan osallistuvuudesta.

Edellisen perusteella voi siis sanoa, että kannatan kolmesta eri tavasta Samuli Häggin kantaa - mikäli olen ymmärtänyt ajatuksen oikein. Hägg nimittäin kirjoittaa: "Kirjallisuudentutkimuksen käsitteitä ei pitäisi opettaa tarkkoina märitelminä vaan kirjallisuuden piirteisiin viittaavina summittaisina kielellisinä eleinä - yhteydessä elävään kirjallisuuteen. [--] Kirjallisuudentutkimuksen luonteeseen kuuluu käsitteiden mukautuminen analysoitavan ja tulkittavan tekstin mukaan.” (Hägg 2011, 38.) Tästä olen täysin samaa mieltä. Kirjallisuustieteelliset ja kirjallisuudenopetuksen käsitteet eivät lokeroi tai anna tarkkarajaisia määrittelyjä, vaan ne kuvailevat tekstin ilmiötä aidon tekstilähtöisesti ja liukuvasti. Hägg kirjoittaa kuitenkin myös, että esimerkiksi Koukin ajama toive yhteisestä sopimuksesta koulun kirjallisuudenopetuksen sisällöksi olisi "järjetön ja mahdoton" (mt, 40). Mahdottomaksi tehtävä voi muodostua, jos pitäisi sopia vaikkapa kertojan kouluun soveltuvasta tarkasta määritelmästä. Tärkeintä ja helposti mahdollista on kuitenkin sopia yhtenäinen tyyli käsitteiden opettamiselle, johon itse ehdotan lokeroinnin sijasta kuvailua. Kuvailevassa analyysissa käsitteet eivät ole lokeroita vaan ne liikkuvat akseleilla.

\section{Akselimalli}

Olen valottanut sitä taustaa, minkä vuoksi lähdin pro gradu -tutkielmassani kehittelemään opetustapaa, joka oikeasti voisi palvella oppimista yksinkertaisesti ja yhtenäisesti koko maassa. Muutos nykyisestä lokeroivasta ajatusmallista akselimalliin ei käytännössä loppujen lopuksi olisikaan suuri, sillä kyse on ennemmin tämänhetkisen opetuksen selkeyttämisestä ja yhdenmukaistamisesta kuin ääripäähyppäyksestä. Moni varmasti osittain jo käyttää akselimallia joidenkin käsitteiden opettamisessa.

Käytän tutkimuksessani kertojan käsitettä esimerkkinä akselimallisesta opetuksesta. Akselimallissa käsitteet eivät ole lokeroita, joihin tulkinnan kohde on väkisin tungettava, vaan kohteen tulkitsemisen työvälineitä. Esimerkiksi kertojan analyysissa kaikkitietävyys on liukuva, adjektiivimainen käsite, jonka avulla voidaan eritellä tietyn tekstin kertojan tiedon määrää. Tätä tietävyyttä voidaan verrata muihin kertojiin ja tulkita, mitä 
mikin kertojan tietävyyden taso tekee millekin tekstille ja tekstin tulkinnalle. Samoin esimerkiksi kertojan luotettavuutta tai persoonaa tulee eritellä akselilinjoilla. Akselimalliseen kertojan opettamiseen ovat Anna-Riikka Ollila ja Reetta Titoff $(2009,37)$ jo muodostaneet yhden mielekkään kaavion pro gradu -tutkielmassaan ”Elämyksellistä antia peruskouluun! Kirjallisuudenopetuksen kehittämisen suuntaviivoja oppilaiden näkökulmasta”. Kertojan miellekartassa kertojan käsite on keskellä ja kuusi liukuvaa alakäsitettä sen ympärillä: ulko-/sisäpuolisuus, luotettavuuden aste, tietävyys/tietämättömyys, osallistumisen aste, näkökulma ja havaittavuus. Näiden kuuden alakäsitteen avulla kertojan analysointi eri näkökulmista onnistuu jokaisessa tekstissä, sillä oppilasta kehotetaan analysoimaan, ei nimeämään: Onko kertoja luotettava? Mikä tekee tämän tekstin kertojan epäluotettavaksi/luotettavaksi? Mitä kertoja tietää? Kykeneekö kertoja tekstissä (todelliseen maailmaan verrattuna) yliluonnollisiin tekoihin tai ajatuksiin? Samalla tapaa esimerkiksi miljöön käsite toimii liukuvasti: ei sitä opeteta niin, että on olemassa kolme erilaista miljöötä, joista jonkin on sovittava kaikkiin vastaan tuleviin teksteihin. Miksi sitten esimerkiksi kertojan käsite opetettaisiin niin, että on joko minäkertoja tai kaikkitietävä kertoja, ja näistä pitää valita, kumpi sopii tulkittavaan tekstiin paremmin?

Uskon akselimallia käytettävän jo useissa luokkahuoneissa joihinkin käsitteisiin. Koska todellinen tarve muutokseen kirjallisuudenopetuksessa on nimenomaan yhdenmukaisuudessa, tasapuolisuudessa ja selkeydessä, tämä toimintatavat kokoava ja järkeistävä uudistus ei oikeastaan vaadi suuriakaan ponnisteluja. Opetussuunnitelmaan tulee sisällyttää tavoite opiskelijan ohjaamisesta soveltavaan käsitteenkäyttöön ja sitä kautta omaan ajatteluun, koska silloin vältymme kasvattamasta lisää nykypäivän mustavalkoisen ajattelun mestareita.

\section{Aloittelija-opettajan ajatuksia opetuksen perustasta}

Opettajan pedagogiset opinnot ovat kohdallani vielä kesken ja edessä kovasti odottamani opettajan työ, mutta tällä hetkellä lähtisin rakentamaan opetustani seuraavalta pohjalta: 1) Käsitteitä tarvitaan oppiaineessa nimeltä äidinkieli ja kirjallisuus. Kuitenkin on oltava sovittuna, mitkä käsitteet tähän oppiaineeseen kuuluvat ja minkä käsityksen mukaan määriteltyinä. Käsitteet opetetaan akselimallilla, ei lokeroivasti, sillä koko kirjallisuuden kenttää ei koskaan voida analysoida samoilla tarkkarajaisilla käsitteillä ja sen yrittäminenkään lukiossa on turhaa. 2) Oppiaineeseen kuuluu tekstianalyysin lisäksi kontekstuaalista kirjallisuuden tulkintaa eli kirjallisuuden tarkastelua todellisen elämän representaationa. Opetukseen kuuluu siis se ajatus, että lukija voi tulkita kirjallisuutta pohtimalla sen avulla omaa ympäristöään, elämäntilannettaan tai yhteiskuntaa. 3) Kolmantena näkökulmana opetuksessani tulisi olemaan kirjallisuussuhteen löytäminen, eli opiskelijan rohkaiseminen etsimään omaa tapaansa nauttia kirjallisuutensa. 
Tähän sisältyy kahden edeltävän lähtökohdan esittely ja opettaminen sille tasolle, että myös ylioppilaskokeessa oppilas voi valita oman mieltymyksensä mukaiset tehtävät.

\section{Viitteet}

${ }^{1}$ Aiempaa keskustelua esimerkiksi (ks. myös lähdeluettelo): Juha Rikama (mm. Hiidenkivi 1:2002, Virke 3:2005, Virke 3:2010, Avain 2:2010, Hiidenkiven verkkolehti 20.5.2011); Tuula Uusi-Hallila (Hiidenkivi 1:2002); Satu Kiiskinen ja Nana Smulovitz (mm. Avain 1:2004); Cecilia Therman (Avain 1:2011); Kai Mikkonen (Avain 1:2011); Samuli Hägg (mm. Avain 2:2006); Karl Grünn (mm. Virke 1:2011, Ylioppilastekstejä-julkaisusarjat 2008 ja 2009); Aino Mäkikalli (Virke 3:2010); Pasi Jääskeläinen (Virke 2:2010); Satu Kiiskinen ja Johanna Virkkunen (Virke 2:2010)

${ }^{2}$ Aineisto esitelty tarkemmin tutkielmassani http://tutkielmat.uta.fi/pdf/gradu04915.pdf

${ }^{3}$ Ks. esimerkiksi Juha Rikama: Millaista kirjallisuuspuhetta koulussa pitäisi opettaa? Kirjallisuudentutkimuksen ja kouluopetuksen hankala suhde. Hiidenkivi 1:2002.

${ }^{4}$ Esimerkkinä kirjallisuusbloggaaja Henna Helmi Heinosen arkistoversiosta 15.11.2010: "Mä luulen, Ella on ollut ennen Linda, tai sitten Ellaa on harkittu muutettavan Lindaksi, ja nimi on unohdettu muuttaa takaisin. [--] Sitä en ymmärrä, miten pari nimeä voisi jäädä muuttamatta yhden sivun verran keskellä kirjaa, kun mä ainakin muutan nimiä findtoiminnolla. Siksi epäilen, että Ellaa olis pikemminkin harkittu muutettavan Lindaksi ja nimeä olisi testattu keskellä sivua, todettu se toimimattomaksi, mutta unohdettu korjata... Vähänkö muuten itse kilahtaisin, jos kävis tuollasta.” (http://hennahelmi.fi/minusta-tuleekirjailija/2010/11/15/ella-oli-linda-tai-aikoi-tulla-lindaksi/)

\section{Lähteet}

ALBER, JAN 2009/2010: Mahdottomat tarinamaailmat - ja mitä niillä voi tehdä. Suom. Laura Karttunen. Teoksessa Luonnolliset ja luonnottomat kertomukset. Jälkiklassisen narratologian suuntia. Toim. Mari Hatavara, Markku Lehtimäki ja Pekka Tammi. Helsinki: Gaudeamus. 44-61.

CHATMAN, SEYMOR I998: The Narrator. Teoksessa Encyclopedia of The Novel. Toim. Paul Schellinger et al. Chicago: Fitzroy Dearborn. 905-910.

CULlER, JONATHAN 2004: Omniscience. Narrative 12:1. 22-34.

HÄGG, SAMULi 20II: Lukion uusi narratologia, jatkokurssi. Teoksessa Kirjallisuus liikkeessä. Lajeja, käsitteitä, teorioita. Toim. Satu Kiiskinen ja Päivi Koivisto. Helsinki: Äidinkielen opettajain liitto. 37-47.

KIRSTINÄ, LEENA 20I I: Analysoi ja tulkitse - klassikkotehtävä. Teoksessa Kirjallisuus liikkeessä. Lajeja, käsitteitä, teorioita. Toim. Satu Kiiskinen ja Päivi Koivisto. Helsinki: Äidinkielen opettajain liitto. 49-58.

KOUKI, ELINA 2009: "Käsitteitä tarpeen mukaan”. Kirjallisuustieteelliset käsitteet lukion kirjallisuudenopetuksessa. Väitöskirja. Turku: Turun yliopisto.

KOUKI, ELINA 20II: Tieteelliset käsitteet opetuksen haasteena. Teoksessa Kirjallisuus liikkeessä. Lajeja, käsitteitä, teorioita. Toim. Satu Kiiskinen ja Päivi Koivisto. Helsinki: 
Äidinkielen opettajain liitto. 25-36.

LOPS 2003: Lukion opetussuunnitelman perusteet 2003. Helsinki: Opetushallitus.

OLLILA, ANNA-RIIKKA JA TITOFF, REETTA 2009: Elämyksellistä antia peruskouluun! Kirjallisuudenopetuksen kehittämisen suuntaviivoja oppilaiden näkökulmasta. Pro gradu -tutkielma. Jyväskylän yliopisto, Taiteiden ja kulttuurintutkimuksen laitos, kirjallisuus.

PÖYHÖNEN, RIIKKA 20II: Kertojan käsitteen hallinta esimerkkinä abiturienttien tekstitaidoista ja opetuksellisista haasteista. Pro gradu -tutkielma. Tampereen yliopisto, Kieli-, käännös- ja kirjallisuustieteiden yksikkö, Suomen kirjallisuus. (Elektroninen julkaisumuoto: http://tutkielmat.uta.fi/pdf/gradu04915.pdf)

RIKAMA, JUHA 2OI I: Vaihtoehtoja. Virke 2/2011. 44. 